\title{
A study on relationship between earnings response coefficient and earnings management: Evidence from Tehran Stock Exchange
}

\author{
Fatemeh Khaksarian*
}

M.Sc. of Finance, Department of Management, Adib Mazandaran University (AMU), Iran

\section{CH R O N I C L E \\ A B S T R A C T}

Article history:

Received May 22, 2013

Received in revised format

28 August 2013

Accepted 15 September 2013

Available online

September 162013

\section{Keywords:}

Tehran Stock Exchange

Earnings management

Earnings response coefficient

\begin{abstract}
This paper presents a study to find the relationship between earnings response coefficient and earnings management on some selected firms listed in Tehran Stock Exchange (TSE). The study uses Johns's model to investigate the behavior of earnings management [Jones, J. J. (1991). Earnings management during import relief investigations. Journal of accounting research, 29(2), 193-228]. In addition, the proposed study uses Ohlson's model [Ohlson, J. A. (1995). Earnings, book values, and dividends in equity valuation. Contemporary accounting research, 11(2), 661-687] to estimate earnings response coefficient. The study gathers the necessary information from 250 firms from TSE market over the period 2006-2012. The result of our survey indicates that there was a negative and meaningful relationship between earnings response coefficient and earnings management.
\end{abstract}

\section{Introduction}

Earnings management plays essential role on predicting investors' behavior and stock prices. A good method for forecasting stock price could create good investment opportunities (Schipper \& Vincent, 2003; Balsam et al., 2003; Bae \& Sami, 2005; Abednazari \& Noravesh, 2013). There are literally various studies on learning more about earnings management. Maranjory et al. (2013) investigated the role of discretionary accruals in the earnings management of some Iranian firms. There were two hypotheses associated with this study on the relationship between income smoothness and discretionary accruals and the proposed study was implemented on selected firms from Tehran Stock Exchange (TSE). They reported that discretionary accruals (DA) leads to the converse relationship among discretionary accruals variation and current and future cash flow. They also reported that the firms with high variation in Iran utilized more discretionary accruals compared with the firms with lower variation. Hayatbakhsh and Esmaeilzade Maghariee (2013) performed a study on relationship between asymmetric information on dividend polices of some TSE companies.

*Corresponding author. Tel: +98-911-2538624

E-mail address: mana_khaky@yahoo.com (F. Khaksarian) 
Dadbeh and Mogharebi (2013) examined the effect of information asymmetry on earning management by examining a sample of 47 TSE companies over the period 2002-2008 based on panel data. They reported that the information asymmetry had some meaningful effects on earnings management. Ahmadi et al. (2013) presented a logistic regression model to measure risk management of receivable accounts on some selected firms from drug industry listed on TSE. They considered the effects of various variables such as current ratio, quick ratio, working capital on total assets and cash flow on economic value added by gathering the necessary information of 29 firms over the period 2006-2011. They reported that the proposed model of this paper was capable of forecasting high profit firms with good probability.

Banimahd and Jalali Aliabadi (2013) performed a study on relationship between earnings management and operating cash flows management on some selected TSE firms. They reported that there was a meaningful relationship between earnings management and operating cash flows management. In other words, earnings management creates and shapes operating cash flows management. In addition, after controlling for the loss reporting, firm size and firm's financial risk, the results indicated that there was a relationship between loss reporting and firm size with the cash flows management. When firms report loss, then operating cash flows increases and as operating cash flows decreases, firm size increases too.

Ghodrati et al. (2013) evaluated the effect of profit quality structures on capital cost and the primary objective was to disclose the effect to investors. They reported that the estimated model could explain 22 percentages of variable changes. This means that there was a weak linear relationship between cost of capital and profit persistence, profit predictability and other variables. Based on the regression estimation they reported that there was a direct relationship between earnings persistence and cost of capital and there was a reverse relationship between earnings predictability and cost of capital.

\section{The proposed study}

In this paper, we present an empirical investigation to study the relationship between earnings response coefficient and earnings management on some selected firms listed in Tehran Stock Exchange (TSE). To study used Johns's model (Johns, 1991) to investigate the behavior of earnings management. The proposed model is as follows,

$$
C_{i t} / T A_{i t-1}=a_{0 j}\left(1 / T A_{i t-1}\right)+a_{1 j}\left(D R E V_{i t}-D R E C_{i t}\right) / T A_{i t-1}+a_{2 j}\left(P P E_{i t} / T A_{i t-1}\right)+e_{i t}
$$

where $T A C_{i}$ represents total accrual, $T A_{i t-1}$ is total assets for firm $i$ in year $t-1, D R E V_{i t}$ is the change in revenue from $t$ to $t-1, D R E C_{i t}$ is the change in receivable accounts from $t$ to $t-1, P P E_{i t}$ is the growth value of equipment for year $t$, and $e_{i t}$ represents residuals. In addition, the proposed study uses Ohlson's model (Ohlson, 1995) to estimate earnings response coefficient as follows,

Price $=\delta_{0}+\delta_{1} B V E+\delta_{2} E P S+\delta_{3}(E P S * D E)+\delta_{4}(E P S * E V A R)+\psi$

where Price represents the closing price in each year, $B V E$ is the book value of each share, $E P S$ is the earnings per share, $D E$ is the ratio of debt to equities and finally $E V A R$ represents the net change in EPS. The study gathers the necessary information from 250 firms from TSE market over the period 2006-2012. The main hypothesis of this survey is as follows,

Main hypothesis: There is a negative and meaningful relationship between earnings response coefficient and earnings management. 


\section{The results}

In this section, we present details of testing the main hypothesis of this survey based on different models. Table 1 demonstrates some basic statistics associated with the proposed study of this paper.

Table 1

The summary of some basic statistics

\begin{tabular}{cccccccc}
\hline \multirow{2}{*}{ Variable } & \multirow{2}{*}{ Mean } & \multirow{2}{*}{ Median } & \multirow{2}{*}{ Standard deviation } & \multirow{2}{*}{ Skewness } & \multirow{2}{*}{ Kurtoses } & \multicolumn{2}{c}{ Jarko-Bra } \\
& & & & & & \\
Statistics & P-value \\
\hline TAC & -0.03406 & -0.02 & 0.262230 & -10.63562 & 234.9386 & 2013956 & 0.000000 \\
DREC & -0.56074 & 0.030000 & 4.768764 & -10.97693 & 149.2379 & 820942.6 & 0 \\
PPE & 0.261176 & 0.220000 & 0.186005 & 0.991845 & 3.609480 & 161.6727 & 0.000000 \\
\hline
\end{tabular}

We have looked at the covariance between DREC and PPE and the correlation ratio has been calculated as 0.03 with $\mathrm{P}$-value $=0.93$, which indicates a weak correlation between two variables. In order to perform regression analysis we need to know whether fixed effect is an appropriate method and Table 2 shows details of our survey.

Table 2

The summary of some statistical test

\begin{tabular}{ccccc}
\hline Test & Statistics & Value & df & Sig. \\
\hline Chaw & $F$ & 1.2344 & & 0.0409 \\
Hasman & Chi-Square & 4.1864 & 2 & 0.1233 \\
\hline
\end{tabular}

Based on the results of Table 2 we realize that fixed effect is appropriate for our study. Table 3 shows details of our findings,

Table 3

The summary of regression analysis

\begin{tabular}{lcccc}
\hline Variable & Coefficient & Standard error & $t$ statistics & Prob. \\
\hline Intercept & 0.017617 & 0.007434 & 2.3697 & 0.0181 \\
$D R E C$ & 0.000675 & 0.000341 & 1.9797 & 0.0481 \\
$P P E$ & -0.19747 & 0.027125 & -7.28 & 0 \\
\hline F-value $=2.947$ (P-value $=0.000)$ & Durbin-Watson $=2.179$ & Adjusted R-Square $=0.26$ & &
\end{tabular}

The results of Table 3 show that the regression model fits well since all t-statistics are meaningful when the level of significance is five percent, Durbin-Watson is within an acceptable limit, which means there is no correlation between residuals and Fisher statistics is significance.

We now consider the main model and first consider basic statistics associated with mean, standard deviation, etc. Table 4 summarizes the results of our survey.

Table 4

The summary of basic statistics

\begin{tabular}{cccccccc}
\hline Variable & Mean & Median & $\begin{array}{c}\text { Standard } \\
\text { deviation }\end{array}$ & Skewness & Kurtoses & \multicolumn{3}{c}{ Jarko-Bra } \\
& & & & & & \\
Statistics & P-value \\
\hline Price & 4394.933 & 2458.000 & 5685.128 & 4.270578 & 30.60352 & 31761.20 & 0 \\
$B E$ & 1885.271 & 1304.230 & 7914.886 & 22.18468 & 556.7610 & 11688980 & 0 \\
EPS & 639.5525 & 468.5200 & 1170.477 & 3.038666 & 27.01835 & 23555.15 & 0 \\
Earnings management & $-7.49 \mathrm{E}-19$ & 0.003025 & 0.233599 & -6.818365 & 154.5776 & 857948.6 & 0 \\
DE & 2.063388 & 1.730000 & 15.02313 & 3.696714 & 245.1163 & 2236983 & 0 \\
\hline EVAR & 11.26447 & -7.996947 & 1524.559 & -11.82005 & 296.2156 & 3291906 & 0 \\
\hline
\end{tabular}


We have also compared the correlation ratios among different variables stated in Table 4 and we did not find any strong correlation. Therefore, there is no threat on having the bad consequences of collinearity. In addition, we have investigated whether we could use fix effect or not and Table 5 summarizes the results of our survey.

Table 5

The summary of some statistical test

\begin{tabular}{ccccc}
\hline Test & Statistics & Value & df & Sig. \\
\hline Chaw & $F$ & 5.169405 & & 0.000 \\
Hasman & Chi-Square & 218.212883 & 2 & 0.000 \\
\hline
\end{tabular}

Based on the results of Table 5 we realize that fixed effect is appropriate for our study and Table 6 shows details of our findings.

\section{Table 6}

The summary of regression analysis

\begin{tabular}{lcccc}
\hline Variable & Coefficient & Standard error & $t$ statistics & Prob. \\
\hline Intercept & 902.8869 & 61.56030 & 14.66671 & 0.0000 \\
$B V E$ & 0.038241 & 0.011861 & 3.224187 & 0.0013 \\
$E P S$ & 2.002890 & 0.057530 & 34.81481 & 0.0000 \\
\hline F-value $=267.41$ & (P-value=0.000) & Durbin-Watson=1.86 & Adjusted R-Square $=0.37$ &
\end{tabular}

The results of Table 6 show that the regression model fits well since all t-statistics are meaningful when the level of significance is five percent, Durbin-Watson is within an acceptable limit, which means there is no correlation between residuals and Fisher statistics is significance.

Next, we examine the relationship between earnings response coefficient and earnings management and the first step is to look whether we could use fixed effect or random effect. Table 7 shows details of our survey.

Table 7

The summary of some statistical test

\begin{tabular}{ccccc}
\hline Test & Statistics & Value & df & Sig. \\
\hline Chaw & $F$ & 5.397716 & & 0.000 \\
Hasman & Chi-Square & 135.544705 & 2 & 0.000 \\
\hline
\end{tabular}

Based on the results of Table 7 we realize that fixed effect is appropriate for our study and Table 8 shows details of our findings.

\section{Table 8}

The summary of regression analysis

\begin{tabular}{lcccc}
\hline Variable & Coefficient & Standard error & $t$ statistics & Prob. \\
\hline Intercept & 3117.538 & 339.6491 & 9.178702 & 0.0000 \\
$B V E$ & -0.012676 & 0.003990 & -3.176700 & 0.0016 \\
$E P S$ & 2.048731 & 0.714685 & 2.866619 & 0.0043 \\
Earning management and EPS & -0.724179 & 0.272498 & -2.657554 & 0.0080 \\
\hline F-value = 15.87 (P-value $=0.000)$ Durbin-Watson= $=1.96$ & Adjusted R-Square $=0.53$ & &
\end{tabular}

The results of Table 8 show that the regression model fits well since all t-statistics are meaningful when the level of significance is five percent, Durbin-Watson is within an acceptable limit, which means there is no correlation between residuals and Fisher statistics is significance. We now repeat 
our results with the presence of control variables. Table 9 summarizes the results of our survey for fixed or random effects.

Table 9

The summary of some statistical test

\begin{tabular}{ccccc}
\hline Test & Statistics & Value & df & Sig. \\
\hline Chaw & $F$ & 6.757990 & & 0.000 \\
Hasman & Chi-Square & 194.546545 & 5 & 0.000 \\
\hline
\end{tabular}

Based on the results of Table 7 we realize that fixed effect is appropriate for our study and Table 10 shows details of our findings.

\section{Table 10}

The summary of regression analysis

\begin{tabular}{lcccc}
\hline Variable & Coefficient & Standard error & $t$ statistics & Prob. \\
\hline Intercept & 3455.161 & 182.2945 & 18.95373 & 0.0000 \\
$B V E$ & -0.014759 & 0.007345 & -2.009427 & 0.0449 \\
$E P S$ & 1.398323 & 0.297196 & 4.705061 & 0.0000 \\
Earning management and EPS & -0.518719 & 0.182757 & -2.838291 & 0.0047 \\
Debt and EPS & 0.011305 & 0.015016 & 2.253561 & 0.0246 \\
EVAR and EPS & -0.000123 & $1.61 \mathrm{E}-05$ & -7.595637 & 0.0000 \\
\hline
\end{tabular}

F-value $=19.69 \quad(\mathrm{P}$-value $=0.000)$ Durbin-Watson=1.96 Adjusted R-Square $=0.63$

The results of Table 8 show that the regression model fits well since all t-statistics are meaningful when the level of significance is five percent, Durbin-Watson is within an acceptable limit, which means there is no correlation between residuals and Fisher statistics is significance. As we can observe from all models, market price has meaningful relationship with change in EPS. There is also a negative and meaningful relationship between earning management and EPS (-0.518719).

\section{Conclusion}

In this paper, we have presented an empirical investigation to study the relationship between meanings management and earnings management coefficient. The study gathered the necessary information from Tehran Stock Exchange and using two well-known methods examined the main hypothesis of this survey. All results of our survey have indicated that there was a negative and meaningful relationship between earnings response coefficient and earnings management.

\section{References}

Abednazari, M., \& Noravesh, I. (2013). A study on relationship between investment opportunities and earnings: A corporate life cycle investigation. Management Science Letters, 3(7), 2039-2048.

Ahmadi, M., Pouraghajan, A.A., \& Salehnezhad, S.H. (2013). Performance measurement of receivable accounts' risk management: A case study of Tehran Stock Exchange. Management Science Letters, 3(6), 1593-1598.

Bae, B., \& Sami, H. (2005). The effect of potential environmental liabilities on earnings response coefficients. Journal of Accounting, Auditing \& Finance, 20(1), 43-70.

Banimahd, B., \& Jalali Aliabadi, M. (2013). A study on relationship between earnings management and operating cash flows management: Evidence from Tehran Stock Exchange. Management Science Letters, 3(6), 1677-1688.

Balsam, S., Krishnan, J., \& Yang, J. S. (2003). Auditor industry specialization and earnings quality. Auditing: A Journal of Practice \& Theory, 22(2), 71-97. 
Dadbeh, F., \& Mogharebi, N. (2013). A study on effect of information asymmetry on earning management: Evidence from Tehran Stock Exchange. Management Science Letters, 3(7), 2161 2166.

Ghodrati, H., Ghazi Fini, S.R., \& Kashaninezhad Abyaneh, M. (2013). An investigation on the effects of the profit quality structures on Iranian firms' capital cost. Management Science Letters, 3(6), 1719-1724.

Hayatbakhsh, A., \& Esmaeilzade Maghariee, A. (2013). A study on relationship between asymmetric information on dividend polices of companies listed in Tehran Stock Exchange. Management Science Letters, 3(7), 2089-2094.

Jones, J. J. (1991). Earnings management during import relief investigations. Journal of accounting research, 29(2), 193-228.

Maranjory, M., Alikhani, R., Zabihzadeh, A., \& Sepehri, P. (2013). The role of discretionary accruals in earnings management: Evidence from Tehran Stock Exchange. Management Science Letters, 3(9), 2399-2404.

Ohlson, J. A. (1995). Earnings, book values, and dividends in equity valuation*.Contemporary accounting research, 11(2), 661-687.

Schipper, K., \& Vincent, L. (2003). Earnings Quality. Accounting Horizons, 17, 97-110. 